\title{
Erratum
}

\section{Rule of Law in China - ERRATUM}

\section{Paul GEWIRTZ}

doi: https://doi.org/10.1017/als.2018.8, Published by Cambridge University Press, 27 March 2018

The above-named paper contained the wrong Copyright Line in the original publication. The Production team would like to apologize for this. The correct Copyright Line is listed below:

(C) The Author 2018. Published by Cambridge University Press and KoGuan Law School, Shanghai Jiao Tong University

\section{REFERENCE}

Paul Gewirtz (2018) "Rule of Law in China_Ji Weidong, Building the Rule of Law in China: Procedure." Discourse and Hermeneutic Community, Vol. I. doi: https://doi.org/10.1017/ als.2018.8. 